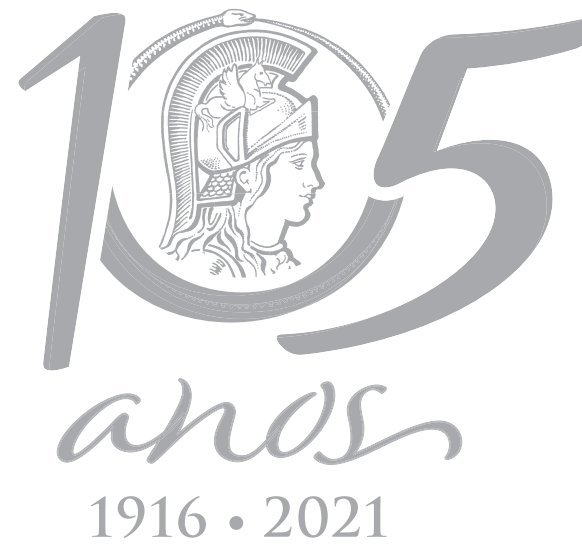

$1916 \cdot 2021$

\title{
Ethanol extracts of mango seeds added to the diet of pigs increases antioxidant capacity of processed pork
}

\author{
LINA R.S. ARAÚJO, PEDRO H. WATANABE, DANILO R. FERNANDES, MARCELLE C.A. \\ MELLO, IRVILA R. DE O. MAIA, ÊNIO C. DA SILVA, ROBERT W. OWEN, GERMANO A.J. \\ DO NASCIMENTO, MARIA T.S. TREVISAN \& EDNARDO R. FREITAS
}

\begin{abstract}
Synthetic antioxidants (e.g.butylhydroxytoluene, BHT) are routinely used for to restrict oxidative processes of meat products, but they are implicated as harmful to the health of humans. Therefore natural alternatives, such as plant antioxidants, have been sought as replacements. Plant antioxidants when added to the diet can be incorporated into meat and reduce the need for the addition of synthetic antioxidants during processing. The objective of this study was to evaluate the effects of ethanol extracts of mango seeds (EEMS) in the diet of pigs on qualitative parameters and total antioxidant capacity of mortadella produced from these animals. Thirty-two pigs with an average 60 days of age were distributed among four treatments: control=no antioxidant; $\mathrm{BHT}=200 \mathrm{ppm} \mathrm{BHT}$; EEMS200 $=200 \mathrm{ppm}$ of EEMS and EEMS400 $=400 \mathrm{ppm}$ of EEMS. At 145 days of age the animals were slaughtered and loin was removed for the preparation of mortadella, which was analyzed during 90 days of storage at $4^{\circ} \mathrm{C}$. A higher content of polyphenolic compounds and, total antioxidant capacity in mortadellas processed with meat of animals which consumed the EEMS400 ration after 60 and 90 days of storage was observed. EEMS polyphenolic antioxidants incorporated into pork through the diet results in an increase of total antioxidant capacity in the processed product.
\end{abstract}

Key words: butylated hydroxytoluene, Mangifera indica, mangiferin, polyphenolic compounds, pork meat.

\section{INTRODUCTION}

Brazil is the fourth largest producer and exporter of pork, with more than $77 \%$ meat produced for the domestic market (Associação Brasileira de Proteína Animal - ABPA 2021). Most pork (89\%) is consumed after processing with only $11 \%$ consumed in its natural form (ABPA 2015). Processed meat products are very susceptible to lipid peroxidation, which is accelerated by processes such as cutting and cooking, leading to loss of quality (La Pomélie et al. 2018). To offset this, synthetic antioxidants such as butylated hydroxytoluene and butylated hydroxyanisole are added to the meat prior to processing and production of sausages (Zhang et al. 2015).

However, synthetic antioxidants are linked to carcinogenic and hepatotoxic effects (Shalaby \& Azzam 2018) and this problem continues to drive research in the area, seeking to replace them with safer substitutes. To this end, studies have been carried out on natural products with antioxidant capacity, by adding them to the diets of animals (Freitas et al. 2015, Martini et al. 2020) allowing assessment of possible effects on the processed meat product (Borges 2009, Martini et al. 2020). 
Solvent extracts of Mango botanical parts are known for their high content of phenolic compounds, such as gallic acid, ellagic acid and mangiferin with high antioxidant potential(Soong \& Barlow 2004). The predominant antioxidant mechanism of action of these extracts is related to electron transfer followed by a loss of protons in the aqueous phase, which makes them a potent antioxidant additive (Stepanic et al. 2013). Dietary phenolic compounds have been reported to be absorbed via the intestinal tract of swine, which are distributed and metabolized in various tissues, including muscle. (Bock et al. 2008). Therefor dietary antioxidant compounds are incorporated into animal meat and may remain in processed meat products such as sausages improving their oxidative stability during storage (Borges 2009), without further addition of exogenous antioxidants during meat product processing.

The object of the present study was to evaluate the effect of diets supplemented with ethanol extracts of mango seeds on $\mathrm{pH}$, color, oxidative stability, phenolic compounds, potential and total antioxidant activity of mortadella made with the meat of these animals.

\section{MATERIALS AND METHODS}

\section{Preparation of Ethanol extract of mango}

The preparation of the ethanol extract of mango seeds was carried out at the Laboratorio de Produtos Naturais e Biotecnologia do Departmento de Química da Universidade Federal do Ceará (UFC). A total of $200 \mathrm{~kg}$ of Tommy and Jasmine mango seeds and husks were obtained from a fruit processing company located in the municipality of Aquiraz, Ceará. The material was washed, exposed to the sun for 48 hours, and oven dried at $55^{\circ} \mathrm{C}$ for a period of 72 hours. Later the material was crushed to start the extraction process according to Freitas et al. (2015). At the end of the process, $2.45 \mathrm{~kg}$ of ethanolic extract (EEMS) was obtained. Because the extract had gel characteristics, it was diluted in degummed soybean oil before admixture with the feed.

EEMS contained $95.5 \mathrm{mg} \mathrm{GAE} / \mathrm{g}$ and a TEAC of $518.68 \mu \mathrm{M}$ equivalent to an $\mathrm{IC}_{50}$ of $175.7 \mathrm{mg} / \mathrm{L}$ compared to a TEAC of $350.8 \mu \mathrm{M}$ and an $\mathrm{IC}_{50}$ of $289.2 \mathrm{mg} / \mathrm{L}$ for BHT. Nevertheless, the same initial concentrations in the feed were adopted for EEMS and the positive control BHT.

\section{Experimental design}

The research protocols used in this study were audited and approved by the Ethics Committee on Animal Research at the Federal University of Ceará, under protocol number 73/2012. The experiments were carried out at the Department of the UFC Animal Husbandry Department. During the experimental period the average temperature recorded was $28.3^{\circ} \mathrm{C}$ with relative air humidity of $70.7 \%$. Thirty-two 60 -day-old castrated male pigs with an average weight of $20.20 \pm 1.34 \mathrm{~kg}$ were used and distributed among 4 treatments in a randomized block design with 8 replications per treatment.

The treatments consisted of the following diets: Control = diets without added antioxidant; $\mathrm{BHT}=$ ration with the addition of $200 \mathrm{ppm} \mathrm{BHT}$; EEMS200 = ration with the addition of $200 \mathrm{ppm}$ EEMS; and EEMS400 = ration with the addition of $400 \mathrm{ppm}$ EEMS. The experimental diets were formulated for growth I (60 to 90 days), growth II (91 to 110 days) and finishing (111 to 145 days) phases, as shown in Table I. The values of the chemical composition of the feed and the nutritional requirements of the animals were set according to the recommendations of Rostagno et al. (2017). Due to the treatments, the inert feed ingredient was proportionally replaced by the antioxidants at predetermined levels. 
Table I. Ingredients and calculated nutritional composition of experimental diets ( $\mathrm{g} / \mathrm{kg}$ as fed basis).

\begin{tabular}{|c|c|c|c|}
\hline Ingredient (\%) & Growing phase I & Growing phase II & Finishing phase \\
\hline Corn & 68.895 & 71.882 & 75.798 \\
\hline Soybean meal & 26.613 & 23.395 & 19.113 \\
\hline Soybean oil & 1.000 & 1.000 & 1.000 \\
\hline Dicalcium phosphate & 1.126 & 1.297 & 1.694 \\
\hline Limestone & 0.651 & 0.603 & 0.580 \\
\hline Mineral and vitamin supplement ${ }^{(1)}$ & 0.300 & 0.300 & 0.300 \\
\hline Common salt & 0.356 & 0.335 & 0.314 \\
\hline Lysine $\mathrm{HCl}$ & 0.195 & 0.223 & 0.269 \\
\hline L-Threonine & 0.035 & 0.042 & 0.076 \\
\hline DL-Methionine & 0.024 & 0.020 & 0.027 \\
\hline L-Tryptophan & 0.000 & 0.000 & 0.002 \\
\hline Inert (washed sand) & 0.805 & 0.903 & 0.827 \\
\hline Total & 100.000 & 100.000 & 100.000 \\
\hline \multicolumn{4}{|c|}{ Calculated chemical composition (g/kg as fed basis) } \\
\hline Metabolisable energy, $\mathrm{kcal} / \mathrm{kg}$ & 3.230 & 3.230 & 3.230 \\
\hline Crude protein & 18.250 & 17.070 & 15.530 \\
\hline Available phosphorus & 0.314 & 0.269 & 0.250 \\
\hline Calcium & 0.635 & 0.552 & 0.512 \\
\hline Sodium & 0.180 & 0.170 & 0.160 \\
\hline Digestible lysine & 0.943 & 0.891 & 0.829 \\
\hline Digestible methionine+cystine & 0.556 & 0.526 & 0.497 \\
\hline Digestible threonine & 0.613 & 0.579 & 0.555 \\
\hline Digestible tryptophan & 0.187 & 0.170 & 0.149 \\
\hline
\end{tabular}

${ }^{(1)}$ Quantity per kg of feed: vitamin A (3199.87 UI), vitamin D3 (649.97 UI), vitamin E (8.5 UI), vitamin K3 (1.00 mg), vitamin B1 (0.33 $\mathrm{mg})$, vitamin B2 $(2.8 \mathrm{mg})$, vitamin B6 $(0.60 \mathrm{mg})$, vitamin B12 $(10.50 \mathrm{mcg})$, folic acid $(0.25 \mathrm{mg})$, pantothenic acid $(9.34 \mathrm{mg})$, niacin (16.00 mg), selenium $(0.30 \mathrm{mg})$, growth promoter $(22.01 \mathrm{mg})$, manganese (14.93 mg), zinc (0.08 g), iron (0.05 g), copper (7.98 mg), iodine $(0.30 \mathrm{mg})$.

During the 90 days of the experimental period, the animals received feed and water ad libitum. The diets provided four times a day were administered in mash form. At the end of the experimental period, the animals were weighed, showing similar performance regardless of diet. Pigs were subjected to a solid 12-hour fast prior to humane slaughter. The carcasses were sawn longitudinally in half and stored at refrigeration temperature $\left(4^{\circ} \mathrm{C}\right)$ for 24 hours.

\section{Collection of meat samples and preparation of mortadella}

From the right half carcass of each animal, a sample of approximately $10 \mathrm{~cm}$ from the Longissimus lumborum muscle was taken. These were vacuum packed and stored at $-20^{\circ} \mathrm{C}$ prior to processing into mortadela sausages.

The mortadelas were prepared at a meat processing company, located in the municipality of Maracanaú, Ceará, Brazil. The bologna was 
prepared with basic pasta without the addition of antioxidant additives (Table II). The emulsion was processed in a temperature-controlled cutter (Cutter 2,5L Metvisa, Brusque, Santa Catarina, Brazil), with the ingredients added gradually until the dough reached the desired consistency.

The emulsified paste was manually embedded with the aid of a $40 \mathrm{~cm}$ stainless steel rod funnel into $40 \mathrm{~mm}$ diameter artificial wrap. Three mortadelas of approximately 200 grams in weight were obtained for each repetition. The mortadellas were steamed at $88{ }^{\circ} \mathrm{C}$ for 1 hour and 30 minutes, cooled in ice-cold water and stored under refrigeration at $4^{\circ} \mathrm{C}$ for up to 90 days. Every 30 days one mortadella of each repetition was analyzed for $\mathrm{pH}$, color, lipid stability, total phenolic compounds, and total antioxidant activity.

\section{pH and color measurement}

The $\mathrm{pH}$ was measured with the aid of a knife electrode (HI-99163, Hanna Instruments, Woonsocket, Rhode Island, EUA). The color was measured with a Konica Minolta CR300

Table II. Composition of mortadella.

\begin{tabular}{|c|c|}
\hline Ingredient & \% \\
\hline Pork meat & 75.00 \\
\hline Backfat & 5.00 \\
\hline Ice water $^{*}$ & 12.00 \\
\hline Refined salt & 2.00 \\
\hline Condiment for mortadella $^{(1)}$ & 0.40 \\
\hline Garlic paste $^{(2)}$ & 0.40 \\
\hline Healing salt & 0.20 \\
\hline Cassava starch & 3.00 \\
\hline Soy protein & 2.00 \\
\hline Total & 100.00 \\
\hline
\end{tabular}

${ }^{(1)}$ Refined salt, natural spices, natural flavorings; ${ }^{(2)}$ Refined salt, sodium nitrite, sodium nitrate. colorimeter (Minolta Company, Osaka, Japão), operating according to the CIE (Commissiom Internationale de l'Eclairage) system measuring units $L^{*}, a$ * and $b$ *.

\section{Lipid stability, phenolic compounds and antioxidant activity}

Thiobarbituric acid reactive substances (TBARS) were quantitated by a colorimetric technique described by Cherian et al. (2002). Results are expressed in $\mu \mathrm{g}$ malondialdehyde (MDA)/g of mortadella. A $10 \mathrm{~g}$ sample of each mortadella was taken and homogenized in $10 \mathrm{~mL}$ of distilled water giving a concentration of $1 \mathrm{mg} / \mathrm{mL}$ (Kurcubic et al. 2014). Samples were centrifuged at 1,500 g for 5 min. (Model 5418R, Eppendorf AG, Hamburg, Germany) and the supernatant used for colorimetric determination of total phenolic compounds (Song et al. 2014), antioxidant potential and total antioxidant capacity (Jang et al. 2008).

\section{Statistical analysis}

Statistical analyzes of the data were performed using the PROC GLM (Statistical Analysis System, version 9.2). A comparison between means was performed by the SNK test with probability set at $5 \%$.

\section{RESULTS}

There was no effect of treatment on the $\mathrm{pH}$ and color components of mortadella's prepared with pig meat ( $P>0.05$ ) (Table III). There was no effect of antioxidant supplementation on the oxidative stability $(P>0.05)$ of the mortadella made with the meat of these animals (Table IV). Mortadella's made with pork meat after dietary supplementation with 200 and 400 ppm of EEMS showed higher concentrations of total phenolic 
Table III. PH value, light intensity $(\mathrm{L} *)$, red intensity $(\mathrm{a} *$ ) and yellow intensity $(\mathrm{b} *$ ) of bologna prepared with pork meat fed with diets containing BHT and EEMS stored under refrigeration at $4{ }^{\circ} \mathrm{C}$ for 90 days.

\begin{tabular}{|c|c|c|c|c|c|c|}
\hline \multirow[b]{2}{*}{ Days } & \multicolumn{4}{|c|}{ Treatments $(\mathrm{T})$} & \multirow[b]{2}{*}{$\mathrm{CV}^{(1)} \%$} & \multirow[b]{2}{*}{ P-value } \\
\hline & Control & ВHт & EEMS200 & EEMS400 & & \\
\hline \multicolumn{5}{|c|}{$\mathrm{pH}$} & & \\
\hline 30 & 6.07 & 6.01 & 6.05 & 6.02 & 1.31 & 0.4653 \\
\hline 60 & 6.04 & 6.03 & 6.07 & 6.03 & 1.31 & 0.7761 \\
\hline 90 & 6.15 & 6.11 & 6.15 & 6.08 & 1.44 & 0.3023 \\
\hline \multicolumn{5}{|c|}{ Component $L^{*}$} & & \\
\hline 30 & 64.39 & 65.14 & 64.01 & 64.55 & 1.73 & 0.0602 \\
\hline 60 & 65.26 & 65.73 & 64.92 & 65.38 & 1.83 & 0.5799 \\
\hline 90 & 64.54 & 65.42 & 64.33 & 64.93 & 1.97 & 0.3635 \\
\hline \multicolumn{5}{|c|}{ Component $a^{*}$} & & \\
\hline 30 & 12.74 & 12.36 & 13.07 & 12.93 & 7.12 & 0.3144 \\
\hline 60 & 12.55 & 12.35 & 12.85 & 12.54 & 9.39 & 0.6094 \\
\hline 90 & 12.09 & 12.16 & 12.80 & 12.61 & 5.43 & 0.3098 \\
\hline \multicolumn{5}{|c|}{ Component b* } & & \\
\hline 30 & 11.33 & 10.97 & 10.86 & 11.13 & 5.30 & 0.8361 \\
\hline 60 & 11.83 & 11.33 & 11.38 & 11.60 & 7.14 & 0.9087 \\
\hline 90 & 11.63 & 11.40 & 11.33 & 11.11 & 8.85 & 0.7800 \\
\hline
\end{tabular}

BHT = diet with 200 ppm of butylated hydroxytoluene; EEMS200 = diet with 200 ppm of ethanol extract of mango seed; EEMS400 = diet with 400 ppm of ethanol extract of mango seed; ${ }^{(1)}$ Coefficient of variation; Values within a row with different superscripts differ significantly at $\mathrm{P}<0.05$ by the SNK test.

compounds at 60 and 90 days of storage compared to the other treatments $(P<0.05)$.

The antioxidant potential did not differ between treatments ( $P>0.05)$. The total antioxidant capacity of mortadella's showed an interaction between treatment $x$ storage time $(P<0.05)$. At 30 days, a greater total antioxidant activity was observed in mortadella's made with the meat of animals supplemented with BHT $(P<0.05)$. At 60 days of storage, the mortadella's formulated with pork meat of animals supplemented with 400 ppm of EEMS showed greater antioxidant capacity in comparison to the control and $200 \mathrm{ppm}$ of EEMS treatment $(P<0.05)$. At 90 days of storage, mortadella's prepared from the meat of pigs supplemented with the two levels of EEMS showed greater total antioxidant activity $(P<0.05)$ when compared to the control.

\section{DISCUSSION}

The $\mathrm{pH}$ results obtained in the present study corroborate those found by Pereira et al. (2011), because the ethanol extract of mango seed added directly prior to the preparation of mortadella did not influence the $\mathrm{pH}$ values during the 21 days of storage. Likewise, there was no effect on the addition of EEMS in the swine feed on the $\mathrm{pH}$ of the mortadelas $(\mathrm{P}>0.05)$. These results are contrary to those obtained by Song et al. (2014) 
Table IV. Lipid stability, total phenolic compounds, potential and total antioxidant activity of mortadella prepared with pork meat fed with diets containing BHT and EEMS stored under refrigeration at $4^{\circ} \mathrm{C}$ for 90 days.

\begin{tabular}{|c|c|c|c|c|c|c|}
\hline \multirow{2}{*}{ Days } & \multicolumn{4}{|c|}{ Treatments (T) } & \multirow[b]{2}{*}{$\mathrm{CV}^{(1)} \%$} & \multirow[b]{2}{*}{ P-value } \\
\hline & Control & BHT & EEMS200 & EEMS400 & & \\
\hline \multicolumn{7}{|c|}{ Lipid stability, MDA g/kg } \\
\hline 30 & 0.61 & 0.71 & 0.68 & 0.68 & 18.95 & 0.4775 \\
\hline 60 & 0.67 & 0.68 & 0.72 & 0.74 & 14.35 & 0.4206 \\
\hline 90 & 0.46 & 0.55 & 0.53 & 0.53 & 13.91 & 0.1237 \\
\hline \multicolumn{7}{|c|}{ Phenolic compounds, $\mu \mathrm{g}$ GAE/g mortadella } \\
\hline 30 & 65.87 & 69.58 & 62.11 & 63.96 & 9.98 & 0.1493 \\
\hline 60 & $63.52^{b}$ & $65.36^{b}$ & $70.31^{\mathrm{a}}$ & $76.85^{a}$ & 7.44 & $<0.0001$ \\
\hline 90 & $61.58^{b}$ & $65.33^{b}$ & $70.87^{\mathrm{a}}$ & $76.36^{a}$ & 7.89 & $<0.0001$ \\
\hline \multicolumn{7}{|c|}{ Antioxidant potential (DPPH), \% } \\
\hline 30 & 23.53 & 25.41 & 22.45 & 22.24 & 17.13 & 0.3885 \\
\hline 60 & 25.14 & 27.14 & 27.96 & 28.71 & 11.38 & 0.1414 \\
\hline 90 & 25.47 & 28.22 & 30.43 & 30.62 & 19.96 & 0.2602 \\
\hline \multicolumn{7}{|c|}{ Total antioxidant activity (ABTS), \% } \\
\hline 30 & $21.75^{b}$ & $31.83^{a}$ & $24.31^{b}$ & $24.64^{b}$ & 19.70 & 0.0031 \\
\hline 60 & $23.78^{b}$ & $25.55^{a b}$ & $23.31^{b}$ & $28.86^{a}$ & 14.04 & 0.0177 \\
\hline 90 & $20.30^{b}$ & $23.88^{a b}$ & $28.41^{a}$ & $27.65^{a}$ & 15.98 & 0.0012 \\
\hline
\end{tabular}

BHT = diet with 200 ppm of butylated hydroxytoluene; EEMS200 = diet with 200 ppm of ethanol extract of mango seed; EEMS400 = diet with 400 ppm of ethanol extract of mango seed; ${ }^{(1)}$ Coefficient of variation; Values within a row with different superscripts differ significantly at $\mathrm{P}<0.05$ by the SNK test.

who reported a reduction in $\mathrm{pH}$ values during the storage of mortadella for 60 days, which they attributed to the gradual growth of lactic acid bacteria. However, the $\mathrm{pH}$ values found in our study are within acceptable levels for good preservation of processed foods, according to Pereira et al. (2011). Chauhan et al. (2019) also observed an increase in the $\mathrm{pH}$ values of the samples of ground pork during storage, relating it to the accumulation of ammonia and the products of amino acid released during protein degradation and utilization of amino acids by bacteria. There is an interdependence between lipid peroxidation and color oxidation. Pigment oxidation can catalyze lipid peroxidation, just as free radicals produced during lipid oxidation can oxidize the iron atom or denature the myoglobin molecule, negatively altering the color of meat products (Lorenzo et al. 2018).

Phenolic compounds can be effective in maintaining the color of meat products during storage, preventing lipid and protein oxidation that occurs during storage (Pateiro et al. 2018). However, no color changes were observed in the mortadella prepared from the meat of animals that received antioxidants in the diet. All brightness values were high when compared to the results of Pateiro et al. (2018). Pale coloration may result from denaturation during the onset of the postmortem phase or may 
be the effect of low $\mathrm{pH}$ on the light-reflecting properties of pigments (Guilherme et al. 2008). This characteristic when present in the carcass is passed on to sausages made with these meats. Therefore, as dietary EEMS did not affect the color parameters of fresh pork meat (Araújo et al. 2021), this characteristic was not altered in the sausages either.

Unlike the present study, Borges (2009) observed that mortadella made with chicken meat after consumption of a diet containing $\mathrm{BHT}$, EEMS or ethanolic extracts from mango peel showed better control of lipid oxidation. There is evidence that natural antioxidants can prevent lipid and protein oxidation in precooked meat products. Rosemary and green tea extracts added directly during the manufacture of Bologna sausages reduced TBARS levels by 73 and $80 \%$, respectively (Jongberg et al. 2013). However, Martini et al. (2020) observed 27.5\% and $21.5 \%$ reduction in the amounts of TBARS after cooking of meat from pigs that consumed a diet containing vegetal extract (red grape skin and oregano) and synthetic antioxidant, respectively, compared to the control diet. However, the lack of effects of antioxidants on the lipid stability of meat products, observed in the present study, is also reported in the literature, because other ingredients used in the preparation of mortadella, such as garlic and healing salt, may have an effect on lipid oxidation of the samples during the storage period, reducing the rancidity of meat products (Costa et al. 2011).

Dietary phenolic compounds are absorbed by the gastrointestinal tract of pigs, distributed and metabolized in various organs and fluids, including muscle (Bock et al. 2008). Therefore, plant extracts added to the feed can increase the amount of total phenolic compounds in the meat (Jang et al. 2008). However, this increase in concentration of total phenolic compounds does not have a direct correlation with TBARS levels, because other components, such as carotenoids, from other feed ingredients, can also prevent lipid peroxidation in meat products (Alvarez-Parrilla et al. 2014).

During heating, a step in the sausage manufacturing process, high molecular weight phenolic compounds can be decomposed and release free forms of gallic and ellagic acids (Soong \& Barlow 2004). Likewise, the fermentation that occurs in stored sausages may decompose these macromolecules and thus increase the content of total phenolic compounds in the products (Song et al. 2014). Thus, it can be inferred that the increase in the content of total phenolic compounds in the samples of the EEMS200 and EEMS400 groups may be due to the occurrence of reactions of this nature resulting in the formation of new phenolic compounds during storage, contributing to the increase in the quantity and phenolic compounds. The formation of new phenolic compounds may have contributed to improvement in the total antioxidant activity of mortadella made with meat from pigs that consumed EEMS in the diet.

\section{CONCLUSIONS}

Mortadella's made from pork produced following supplementation of swine diets with extract rich polyphenol content resist thermal processing and although $\mathrm{pH}$, color, oxidative stability and antioxidant potential remain unaffected, the content of total phenolic compounds increased significantly correlating with total antioxidant activity.

The results of this study confirm the close relationship between pig nutrition and the quality of meat products. Further studies are needed in order to establish a better dose-response 
for EEMS to control the lipid stability of meat products processed during storage.

\section{Acknowledgments}

To the Comissão de Aperfeiçoamento de Pessoal de Nivel Superior (CAPES) for granting the scholarship, to the Fundação Cearense de Apoio ao Desenvolvimento Científico e Tecnológico (FUNCAP) for financial support; to the production manager Mr. José Augusto Stoco and to the Veterinary Doctor Fernando Santos Silva for his collaboration in the production of the sausages.

\section{REFERENCES}

ALVAREZ-PARRILLA E, MERCADO-MERCADO G, ROSA LA DE LA, DÍAZ JAL, WALL-MEDRANO A \& GONZÁLEZ-AGUILAR GA. 2014 Antioxidant activity and prevention of pork meat lipid oxidation using traditional Mexican condiments (pasilla dry pepper, achiote, and mole sauce). Food Sci Technol 34: $371-378$

ARAÚJO LRS ET AL. 2021. Dietary ethanol extract of mango increases antioxidant activity of pork. Anim 15(2): 100099.

ABPA - ASSOCIAÇÃO BRASILEIRA DE PROTEÍNA ANIMAL. 2015. Relatório Anual 2015. ABPA. 248p. Available: http:// abpa-br.org/wp-content/uploads/2018/10/relatorioanual-2015.pdf [10 mar. 2019].

ABPA - ASSOCIAÇÃO BRASILEIRA DE PROTEÍNA ANIMAL. 2021. Relatório Anual 2021. ABPA. 148p. Available: https:// abpa-br.org/relatorios/ [26 mai. 2021].

BOCK C, WALDMANN KH \& TERNES W. 2008. Mangiferin and hesperidin metabolites are absorbed from the gastrointestinal tract of pigs after oral ingestion of a Cyclopia genistoides (honeybush tea) extract. Nutr Res 28(12): 879-891.

BORGES A DA S. 2009. Uso de compostos extraídos da manga (Mangifera indicus l.) no controle da oxidação lipídica na carne de frango, em produto cárneo tipo mortadela e ovos de consumo. 2009. 125f. PhD thesis, Universidade Federal do Ceará, Fortaleza.

CHAUHAN P, PRADHAN SR, DAS A, NANDA PK, BANDYOPADHYAY S \& DAS AK. 2019. Inhibition of lipid and protein oxidation in raw ground pork by Terminalia arjuna fruit extract during refrigerated storage. Asian-Australas J Anim Sci 32(2): 265.

CHERIAN G, SELVARAJ RK, GOEGER MP \& STITT PA. 2002. Muscle fatty acid composition and thiobarbituric acid-reactive substances of broilers fed different cultivars of sorghum. Poult Sci 81: 1415-1420.

COSTA MCR, SILVA CA, BRIDI AM, FONSECA NAN, OBA A, SILVA RAM, SILVA PA, YWAZAKI MS \& SPOTO DBD. 2011. Estabilidade lipídica do pernil e da linguiça frescal de suínos tratados com dietas com alta concentração de ácido fítico. Semin Ciênc Agrár 32(sup.1): 1863-1872.

FREITAS ER, BORGES A DA S, PEREIRA ALF, ABREU VKG, TREVISAN MTS \& WATANABE PH. 2015. Effect of dietary ethanol extracts of mango (Mangifera indica L.) on lipid oxidation and the color of chicken meat during frozen storage. Poult Sci 94 : 2989-2995.

GUILHERME CA, SANTOS LHM DOS, BECHER L \& STREMEL PI. 2008. Alterações bioquímicas na cor da carne. In: Proceddings of Semana de tecnologia em alimentos, 6 - Universidade Tecnológica Federal do Paraná - UTFPR Campus Ponta Grossa 2(29).

JANG A, LIU X-D, SHIN M-H, LEE B-D, LEE S-K, LEE JH \& JO C. 2008. Antioxidative Potential of Raw Breast Meat from Broiler Chicks Fed a Dietary Medicinal Herb Extract Mix. Poult Sci 87: 2382-2389.

JONGBERG S, TORNGREN MA, GUNVIG A, SKIBSTED LH \& LUND MN. 2013. Effect of green tea or rosemary extract on protein oxidation in Bologna type sausages prepared from oxidatively stressed pork. Meat Sci 93: 538-546.

KURCUBIC VS, MASKOVIC PZ, VUJIC JM, VRANIC DV, VESKOVICMORACANIN SM, OKANOVIC DG \& LILIC SV. 2014. Antioxidant and antimicrobial activity of Kitaibelia vitifolia extract as alternative to the added nitrite in fermented dry sausage. Meat Sci 97: 459-467.

LA POMÉLIE D, SANTÉ-LHOUTELLIER V, SAYD T \& GATELLIER P. 2018. Oxidation and nitrosation of meat proteins under gastro-intestinal conditions: Consequences in terms of nutritional and health values of meat. Food Chem 243: 295-304.

LORENZO JM, PATEIRO M, DOMINGUEZ R, BARBA FJ, PUTNIK P, KOVAČEVIĆ DB, SHPIGELMAN A, GRANATO D \& FRANCO D. 2018. Berries extracts as natural antioxidants in meat products: A review. Food Res Int 106: 1095-1104.

MARTINI S, TAGLIAZUCCHI D, MINELLI G \& LO FIEGO DP. 2020. Influence of linseed and antioxidant-rich diets in pig nutrition on lipid oxidation during cooking and in vitro digestion of pork. Food Res Int 137: 109528.

PATEIRO M ET AL. 2018. Guarana seed extracts as a useful strategy to extend the shelf life of pork patties: UHPLCESI/QTOF phenolic profile and impact on microbial inactivation, lipid and protein oxidation and antioxidant capacity. Food Res Int 114: 55-63.

PEREIRA ALF, VIDAL TF, TEIXEIRA MC, OLIVEIRA PFDE, POMPEU RCFF, VIEIRA MMM \& ZAPATA JFF. 2011. Antioxidant effect of mango seed extract and butylated hydroxytoluene in bologna-type mortadella during storage. Ciênc Tecnol Aliment 31(1): 135-140.

ROSTAGNO HS ET AL. 2017. Tabelas brasileiras para aves e suínos: Composição de alimentos e exigências nutricionais. 4th edition. UFV, DZO, Viçosa, MG, BRA. 
SHALABY E \& AZZAM GM. 2018. Antioxidants in Foods and Its Applications. $1^{\text {th }}$. London: IntechOpen, $168 \mathrm{p}$.

SONG E-Y, PYUN C-W, HONG G-E, LIM K-W \& LEE C-H. 2014. Effect of Addition of Allium hookeri on the Quality of Fermented Sausage with Meat from Sulfur Fed Pigs during Ripening. Korean J Food Sci Anim 34(3): 263-272.

SOONG Y-Y \& BARLOW PJ. 2004 Antioxidant activity and phenolic content of selected fruit seeds. Food Chem 88(3): 411-417.

STEPANIC V, TROSELJ KG, LUCIC B, MARKOVIC Z \& AMIC D. 2013 Bond dissociation free energy as general parameter for flavonoid radical scavenging activity. Food Chem 141: 1562-1579.

ZHANG C, LUO J, YU B, ZHENG P, HUANG Z, MAO X, HE J, YU J, CHEN J \& CHEN D. 2015. Dietary resveratrol supplementation improves meat quality of finishing pigs through changing muscle fiber characteristics and antioxidative status. Meat Sci 102: 15-21.

\section{How to cite}

ARAÚJO LRS, WATANABE PH, FERNANDES DR, MELLO MCA, MAIA IRDO, DA SILVA EC, OWEN RW, DO NASCIMENTO GAJ, TREVISAN MTS \& FREITAS ER. 2021. Ethanol extracts of mango seeds added to the diet of pigs increases antioxidant capacity of processed pork. An Acad Bras Cienc 93: e20210406. DOI 10.1590/0001-3765202120210406.

Manuscript received on March 3, 2021;

accepted for publication on August 26, 2021

\section{LINA R.S. ARAÚJO ${ }^{1}$}

https://orcid.org/0000-0003-3325-4130

\section{PEDRO H. WATANABE}

https://orcid.org/0000-0002-1010-2305

DANILO R. FERNANDES ${ }^{1}$

https://orcid.org/0000-0001-9801-8273

MARCELLE C.A. MELLO'

https://orcid.org/0000-0001-7345-5995

IRVILA R. DE O. MAIA

https://orcid.org/0000-0002-1960-2314

ÊNIO C. DA SILVA ${ }^{3}$

https://orcid.org/0000-0002-6716-0792

ROBERT W. OWEN ${ }^{4}$

https://orcid.org/0000-0001-8264-2207

GERMANO A.J. DO NASCIMENTO ${ }^{1}$

https://orcid.org/0000-0003-3360-5922

\section{MARIA T.S. TREVISAN ${ }^{2}$}

https://orcid.org/0000-0003-1274-7497

\section{EDNARDO R. FREITAS ${ }^{1}$}

https://orcid.org/0000-0001-7226-9517

'Departamento de Zootecnia, Universidade Federal do Ceará, Av. Humberto Monte, s/n, Blocos 810, Campus do Pici, 60440-900 Fortaleza, CE, Brazil

${ }^{2}$ Departamento de Química, Universidade Federal do Ceará, Av. Humberto Monte, s/n, Bloco 938, Campus do Pici, 60440-900 Fortaleza, CE, Brazil ${ }^{3}$ Pós-graduação IFOPE, Rua Gonçalves Dias, 55, Funcionários, 30140-090 Belo Horizonte, MG, Brazil

${ }^{4}$ Division of Preventive Oncology, National Center for Tumor Diseases and German Cancer Research Center (DKFZ), Im Neuenheimer Feld 460, 69120 Heidelberg, Germany

Correspondence to: Lina R.S. Araújo

E-mail:linaaraujo@gmail.com

\section{Author Contributions}

All authors contributed to the study conception and design. Material preparation, data collection and analysis were performed by Lina Raquel Santos Araújo, Pedro Henrique Watanabe, Ednardo Rodrigues Freitas, Danilo Rodrigues Fernandes, Marcelle Craveiro Abreu Mello, Irvila Ricarte de Oliveira Maia and Ênio Campos da Silva. The first draft of the manuscript was written by Lina Raquel Santos Araújo and all authors commented on previous versions of the manuscript. All authors read and approved the final manuscript.

- Conceptualization: Pedro Henrique Watanabe and Ednardo Rodrigues Freitas; Methodology: Pedro Henrique Watanabe, Ednardo Rodrigues Freitas and Lina Raquel Santos Araújo; Formal analysis and investigation: Lina Raquel Santos Araújo, Danilo Rodrigues Fernandes, Marcelle Craveiro Abreu Mello, Irvila Ricarte de Oliveira Maia and Ênio Campos da Silva; Writing - original draft preparation: Lina Raquel Santos Araújo; Writing review and editing: Pedro Henrique Watanabe, Robert Wyn Owen, Germano Augusto Jerônimo do Nascimento, Ednardo Rodrigues Freitas, Danilo Rodrigues Fernandes, Marcelle Craveiro Abreu Mello, Irvila Ricarte de Oliveira Maia, Ênio Campos da Silva and Lina Raquel Santos Araújo; Funding acquisition: Pedro Henrique Watanabe; Resources: Pedro Henrique Watanabe, Maria Teresa Salles Trevisan and Ednardo Rodrigues Freitas; Supervision: Pedro Henrique Watanabe and Lina Raquel Santos Araújo

\section{(cc) BY}

